the "Kew Question" has assumed proportions, and may have consequences, meriting for it a thorough ventilation ; and I permit myseli to believe that you may not be unwilling to receive further remarks on those points in my "Statement" to which Dr. Hooker has condescended to reply.

Sheen Lodge, 'Oct. 30

RICHARD OWEN

\section{Physics for Medical Students}

I AM and have been a "medical student" for many years, and hope to live in that capacity for some years more. I admit that I ought to know " the relation between the surface temperature of the body, the quantity of heat passing away from it, and the amount of heat generated in the body by the food given to a patient," but I do not know all this, and I have never discovered anyone who can tell me where I can learn it or how I can find it out by any efforts of my own.

Moreover, I have been unable to get a clear and satisfactory answer to the following simple questions, and have failed to find anyone who will explain to me accurately how $I$ am to set to work to get the information so much desired :- "What is the quantity of heat generated in the body by the food, and how is it to be determined? How is the quantity of heat that passes away from the body in a given time to be estimated with anything approacting to accuracy?" If my friend and colleague Prof. Adams will be so kind as to give answers to these questions in NATURE, I can assure him he will confer a great favour upon many worke; $\dot{s}$ and thinkers in my profession, besides proving the value of such questions as that objected to by $\mathrm{Mr}$. Heath for medical students. At this time we doctors are much in need of physical help. I have no doubt that physicists will $\mathrm{b}=$ much astonished at our igrorance, but never mind that; we are quite rea $y y$ to lears, ant don't mind being laughed at or even spoken of with slight contenpt by our physical friends if they will only help us. Nay, we will suffer anything from those who will instruct us so that we may be able to set to work upon living people wio are "generating" and giving off heat, and determine with ascuracy the different rate at which heat is "generated" and given of under different circumstances.

Prof. Adams asks whether "the production of heat in t"le human body by the consumption of food" is "carriej on on principles entirely different from those of the production of steam in a boiler," and seems to regard it as one of the "mildest of questions", in heat that can be proposed for a medical student to answer. Will he answer his own question by asserting that the principles are the same in the two cases? Heat in the body, steam in the builer--heat, steam; body, boiler!-or shall the question be revised before it is proposed to the student?

I have not the slightest doubt about the usefulness of a knowleige of physics to those who are working at medicine, and quite agrice that the rising generution of medical students should be taught physics. But this is a very different thing from teaching people to fancy that living things are mechanisms, machines, galvanic batteries, or molecular apparatuses. I venture to think that some of the most distinguished:physicists are too fond of desesting their own department for the purpose of trying to make people believe that there is an analogy between steam-boilers and human bodies, when no one has yet succeeded in proving that there is any true analogy whatever.

King's College, London

LiONEL S. BeALE

IN the last number of Nature Mr. Adams, of King's College, criticised the remarks made by $\mathrm{Mr}$. Heath in his introductury adirress upon the character of the London University medical examinations, and of the first, the preliminary scientific, more es yecially. It scarcely needed a column and a quarter of close type for Mr. Adams to tell us that a medical man should be acquainted with physical laws and phenomena, and that in his opinion the mathematical question quoted by Mr. Heath was not too difficult to be fittingly placed in the examination paper. The former point is beyond question, and the latter is not to be settled by deciaring the statement of the editor of the Lancet to be "shallow." As to the view that a medical man should be able to estimate precisely "the amsunt of heat lost through a blanket or a seal-skin coat," I will only say tirat it seems to me that a slight con-ideration of the physical and physiological coxditions involved, and their variations in different instances, will suggest the hope that he will n.t waste his time in attempting such feats, simple as they may be deemed in physical laboratories. I wiil not take up space in commenting upon Mr. Adams' argy- ments a!d illustrations in support of his position, since they do but go to show that a medical man should have some knowletge of natural philosophy and its applications to the conditions with which he has tu deal, and not that he stiould be driven to expend his time, already overcharged with mucin more that is of no possible use to him, upon mathematical processes which concern astro. nomers, chemists, and engineers. There is no doubt that to give a scientific character to medicine, exact quantitative methods must be applied to physiology and pathology, but it should be the work of men specially trained and devoted to the purpose. It has for some time past been commonly agreed that the medical student's education is such that he is urged to acquire a quantity of information with little regard to its use and digestibility. He has a great deal to learn in a short time. The chief part of his education consists, or should consist, in observing and comparing morbid conditions, and in learning or devising means for their relief and cure. Whatever time he spends upon what is not requisite, or has little direct bearing upon his art, implies time mis-spent and injury to the sufferers be will later attend. Prof. Huxley did not go too far in saying that the conduct of hose who impose useless knowledge upon medical students is mply criminal.

Junior Athenæum Club

F. LYNDON ATTWOOD

\section{NORTH POLAR EXPLORATION}

$\mathrm{N}$ the last number of the Mittheilungen Dr. Petermann publishes his 67th paper on the Geography and Discoveries of the Polar Regions, in which he gives an abstract of what has been done during the last three or four months.

The two projected Norwegian expeditions into the Siberian Seas, under the guidance of Captains Jensen and Mack, have at present been unfortunately frustrated; the former from a damage to the screw of the steamer, the latter from inability to penetrate the masses of ice. However, a projected scientific expedition for next year is excitiag much interest at Tromsö. The French Expedition, und Ambert and Mack, has not yet put to sea, having been detained by the delay in settling the estate of Lambert, who left a large sum to be devoted to this purpose. This is much to be regretted, as Captain Mack has already distinguished himself by penetrating farther than any other discoverer into the Siberian Sea.

However, the much-talked-of and bold expedition under M. Octave Pavy, has, it is understood, at last left San Francisco, with what results remains to be seen. He expects to reach Wrangell Land by September I, making his way farther northward in sledges, and hopiny to come to open sea about May 1873 . He will then proceed towards the Pole by means of a raft of somewhat novel construction, consisting of four hollow cylinders provided with a deck, and capable of holding all necessary provisions for Pavy and his small party for two years, by which time he expects to have reached the Pole, and re. turned to San Francisco. His companions are Dr. Chesmore, who has travelled much in Alaska; Captain Mike, who a few years ago attempted to cross the Atiantic in a vessel of somewhat similar construction to Pavy's; Watkins, a renowned Rocky Mountain hunter ; and two sailors of whaling experience: in all, the expedition will consist of six men.

The latest news from the North American Expedition is contained in a letter from Dr. Bessels to Dr. Petermann, dated August 23, I87I, at which time the expe dition had reached Tessinsalk, the most northerly Danish settlement in Greenland, in lat. $73^{\circ} 24^{\circ} \mathrm{N}$., and long. $56^{\circ}$ I2 $2^{\prime} \mathrm{W}$. Further details as to this expedition will be found in NATURE for September 19.

One of the most impnrtant and best fitted out expeditions is the Austrian one under Paver and Weyprecht, which left Tromsö in July, for the purpose of exploring the unknown region north of Siberia, to wh'ch they are prepared to devote three years. By the latest advices, about the end of July, the expedition was fairiy on the road to its field of labour, and Count Wiltschak 
was to follow with a store of provisions, to be deposited near the Ice Cape, on the north of Nova Zembla, in case the expedition should be compelled to turn back.

Of the outfit and plan of the Swedish expedition we gave an account in NATURE for August 29. It left Tromsö on the 3Ist of July, and when last heard of was off the north-west point of Spitzbergen.

We are also favoured with a letter from Dr. Petermann, dated Gotha, October II, from which we learn that the land on the east of Spitzbergen, which for the last 355 years has had a varying position on the map, has this year for the first time been reached by Captain Altmann of Hammerfest, and again on August 16 last by Captain Nils Johnsen of Tromsö, in his little sailing yacht the Lydeana, who landed and explored it. Captain Johnsen saw the island first when in N. lat. $78^{\circ} \times 8^{\prime} 46$, and E. long. $30^{\circ}$; in the maps of 1617 it was marked as Wiche Land, between $78 \frac{1}{3}^{\circ}$ and $75^{1} \frac{1}{4}^{\circ} \mathrm{N}$. lat. On the $x 7$ th of August he anchored near to the north point in $79^{\circ} 8^{\prime} \mathrm{N}$. lat. and $30^{\circ} 15^{\prime} \mathrm{E}$. long., for the purpose of landing and exploring the place. What Captain Altmann, looking from a distance, took to be three islands, Johnsen found in reality one, the high hills being connected by low lying land, with several outlying islets. On no part of the land has he found extensive snow-fields, and saw only one small glacier on the south-east coast, while, on the contrary, there are many large streams entirely free from ice. The greatest length of the land Captain Johnsen has found to be 44 geographical mnles. Large quantities of driftwood extended here and there to about roo feet from the coast, and rose to the height of at least 20 feet. The island abounds in the usual Polar fauna, the plentifulness of seals, especially Phoca Groenlandica, being noted by Johnsen. The reindeer on the island are spoken of as the largest and fattest which anyone on board the Lydeana had ever seen. The rocks seem to be principally of the quartz and argillaceous kind, and some fossils have been sent to Sweden and to Zurich. Captain Johnsen explored the east, south-east, and north-east coasts, and so far as his observations went, ice is to be found only on the north coast.

The fact of greatest significance in this latest news from these quarters is that for many months in the year the sea around Spitzbergen is almost entirely free from ice; a position long and sagaciously maintained by Dr. Petermann.

"Of interest," says the Academy," "in connection with this subject is an account of the finding of the relics of Barents' expedition of 1597 to Novaia Zemlia, by Captain Carlsen in $187 \mathrm{r}$, prepared by $M$. de Jonge, and newly published under the auspices of the Dutch government at the Hague. The pamphlet contains the journal kept by Carlsen, and a minute description of the relics, accompanied by a photograph of these in a group, and charts comparing the Novaia Zemlia of Barents with the island as mapped from our present knowledge of it."

\section{RESEARCHES IN GREENLAND*}

$\mathrm{W}$

HEN I wrote to you last from Copenhagen, I anticipated that my season would be very short; and my anticipations were correct. The season, however, in Greenland has been long and brilliant. In the middle of May floe ice disappeared in Umenak Fiord, which was fully six weeks earlier than usual ; and in April, in Godhavn men went about in summer attire. When I arrived (on July 6) the land was covered with flowers, the butterflies were beginning to appear, and almost all snow had vanished from the sea-level up to $2,000 \mathrm{ft}$. Since then, with the exception of a bad week in the Waigat, I have enjoyed the most exquisite weather that it is possible to imagine. In this arctic region it has only frozen on two nights, and during the daytime the thermometer has * Copy of a letter addressed to Mr, R. H. Scott, F.R.S., and kindly forwarded by him to us, $-\mathrm{ED}$. ranged fifom $50^{\circ}$ to $70^{\circ}$. Until recently we have also had a high barometer; and, upon the whole, very little wind.

I have been upon Hare Island for three days, and have also been to Umenak, but the chief part of my time has been spent in the Waigat, where you would be surprised, perhaps, to find that a great deal remains to be done. I have found a great valley leading into the interior of Disco, and have gone up it a hard day's march. I have ascended one of the highest of the peaks on the Noursoak side of the Waigat, and looked down upon the great valley which occupies almost the whole of its interior. The lakes, as given upon Rink's map from reports of Eskimo, do not exist, but there is one very large lake which has a glacier or glaciers coming into it at perhaps $2,000 \mathrm{ft}$. above the sea. This valley is the most important one hitherto discovered in North /Greenland. The river flowing down it has the character of a river, and not of a torrent; and, after descending through many windings a course of at least 100 miles, it pours into the sea a volume of water equal to that of the Rhone at the Lake of Geneva. At half a mile from the shore I found the water fresh.

In Umenak Fiord $I$ ascended a mountain of about 7,000 ft. with five Greenlanders, and took my theodolite to the top. As you know the weight of the instrument, you will be partly able to appreciate this performance. The ascent, first over swamp, then over basalt debris which reposed insecurely upon solid basalt, and finally, at the top, up columnar basalt, was a sweet thing of its kind. The picture of your humble servant being lowered by a rope, dangling like a bundle from a crane, will, perhaps, to some people, be more interesting than the results obtained by the theodolite. These, however, were not unimportant. My peak, an isolated one, commanded a view of almost the whole of the Umenak district (which contains the highest mountains of Greenland proper), and a magnificent view of the "inland-ice." I found the general elevation of the mountains exceeded by about $2,000 \mathrm{ft}$. the height previously assigned to them. Of the altitude of the "inland ice" I shall write on a subsequent occasion.

A large part of my time in the Waigat was occupied by the measurement of a base line. This was the most important piece of work that I undertook, and it was successfully executed. I find the Waigat to Lave in some places scarcely half the width which our maps give it. I find its mountains to be about double the altitude that they have been supposed to be ; and Hare Island I find to be twice the length represented upon the Admiralty Chart; Hare Island has some points of particular interest. I got from it a rather large collection of fossil plants, and went to its top $(\mathrm{r}, 800 \mathrm{ft}$.). From the summit, at midnight, I distinctly recognised the mountain called Sanderson's Hope, near Upernavik, which was distant from me I40 miles!

I have made an excellent journey, full of interest. My collections are at least as valuable as those of 1867 , though, as far as I know, they do not contain anything of the importance of the Magnolia. I have, however, even larger collections of fossil plants than before, and from localities which I did not visit in 1867. My stone implements are very numerous, and of good quality, and the natural history specimens are not few in number. Altogether I am very well content.

EDWARD WHYMPER

Written on board the brig Hvalfisken as it proceeded out of the harbour of Godhavn, Sept. 10, I872.

\section{THE HELVETIC SOCIETY OF NATURAI SCIENCES}

THE 55th Session of this Society was held at the ancient city of Fribourg on the I9th, 2oth, and 2 Ist of August last, and of it we have again to tell of an overwhelmingly hospitable reception by "our hosts of Fribourg;" a well-attended opening address by the President, Dr. Thurler; sectional séances, at which 